\title{
Factores que afectan al desarrollo inicial de resistencias a compresión en hormigones de ceniza volante activados alcalinamente (sin OPC)
}

\author{
Factors affecting early compressive strength of alkali activated \\ fly ash (OPC-free) concrete
}

\author{
A. Fernández-Jiménez ${ }^{(*)}$ y A. Palomo(*)
}

Recepción/Received: 17-VII-06

Aceptación/Accepted: 20-XII-06

RESUMEN

Este trabajo presenta los resultados de una investigación experimental llevada a cabo para evaluar las principales características de un nuevo tipo de hormigón fabricado solamente con ceniza volante activada alcalinamente (AAFA); es decir, sin cemento Portland comercial (OPC). Los resultados de los ensayos realizados para determinar las propiedades específicas del hormigón fresco y el desarrollo de resistencias mecánicas mostraron que la mayoría de los factores que afectan al proceso de fabricación y a las propiedades finales de los hormigones de cemento Portland (relación agua/cemento, condiciones de curado, etc.) también afectan a la preparación y calidad final de estos nuevos materiales. También fueron estudiados otros parámetros específicos de los hormigones de AAFA (la naturaleza y concentración del álcali presente en el sistema) para determinar su papel en el proceso de fraguado y endurecimiento.

Palabras clave: activación alcalina, ceniza volante, hormigón, resistencias a compresión, dosificación.
SUMMARY

This paper presents the findings of experimental research into the chief characteristics of a new type of concrete made solely with alkali activated fly ash (AAFA): i.e., free of ordinary Portland cement (OPC). The results of testing to determine specific properties of the fresh concrete and the development of its mechanical strength showed that most of the factors that affect the manufacture and final properties of Portland cement concrete (water/cement ratio, curing conditions, etc.) also impact the preparation and final quality of this new material. $A$ number of parameters specific to AAFA concrete (nature and concentration of alkali present in the system) were also explored to determine their role in the setting and hardening process.

\section{INTRODUCCIÓN}

La activación alcalina de materiales (1-7) es un proceso químico en el que se produce rápidamente una transformación parcial o total de los componentes vítreos/amorfos
Keywords: alkali activation, fly ash, concrete, compressive strength, dosage.

\section{INTRODUCTION}

The alkaline activation of materials (1-7) is a chemical process that rapidly transforms certain partial or totally vitreous/amorphous compounds into compact cementitious

(*) Instituto de Ciencias de la Construcción Eduardo Torroja (CSIC) (Madrid, España).

Persona de contacto/Corresponding author: anafj@ietcc.csic.es 
del material en estructuras cementicias compactas. En general, la activación alcalina puede dar lugar a dos tipos de materiales cementantes: compuestos basados en Si/Ca y/o basados en Si/Al. La activación de metacaolín y de la ceniza volante (FA) constituyen ejemplos típicos del último (8-11).

El presente trabajo muestra los resultados de una investigación sobre la activación alcalina de cenizas volantes (AAFA). Éste es un procedimiento singular donde el polvo gris de la ceniza (FA) es mezclado con una solución alcalina (activadores alcalinos) y, tras un curado a temperatura moderada, se obtiene un material con propiedades cementantes. El componente vítreo de la ceniza volante se transforma en un cemento bien compactado. En investigaciones previas $(7,11,12)$ se comprobó que el principal producto de la reacción formado en AAFA es un gel amorfo de aluminosilicato con característica y propiedades de un "precursor zeolítico". De acuerdo con las investigaciones de Davidovits (7) y Palomo (12), la cristalización de zeolitas puede ser el hipotético estado final de la ceniza activada alcalinamente. El orden a corto rango de este "precursor zeolítico" consiste en una estructura tridimensional donde el Si presenta una gran variedad de entornos $(11,12)$. En estos sistemas también ha sido detectada la presencia de pequeñas cantidades de hydroxisodalite y herschelite, así como de otras zeolitas cristalinas (11-14).

En la literatura pueden encontrarse datos sobre el desarrollo mecánico de pastas y morteros activados alcalinamente $(10,13,14,15)$, sin embargo, existen muy pocos datos sobre la fabricación de hormigones de ceniza volante activada alcalinamente sin cemento Portland.

El propósito principal de este trabajo es determinar hasta qué punto los factores de diseño de mezcla (proporciones de la mezcla, procedimiento de mezclado, tiempo de curado, temperatura de curado, naturaleza y concentración del activador alcalino, relación disolución/ceniza, etc.) afectan a su fraguado y endurecimiento. Así como al desarrollo a edades iniciales de resistencias a compresión de hormigones de ceniza volante activados alcalinamente. En este aspecto se ha realizado un estudio comparativo entre los nuevos hormigones de ceniza activada y los hormigones de OPC.

\section{EXPERIMENTAL}

\subsection{Materiales}

En estos ensayos se utilizaron dos cenizas volantes españolas tipo $\mathrm{F}$ y un cemento comercial (CEM I $52.5 \mathrm{R}$ descrito en la norma UNE 80-300:2000 IN). En la Tabla 1 se muestra la composición química y la superficie específica de los materiales utilizados. De los datos de esta tabla se structures. In general, alkaline activation yields two types of cementitious materials: Si- and Ca-based or Siand Al-based compounds. The alkali activation of metakaolin and fly ash (FA) constitute typical examples of the latter (8-11).

The present paper reports on research conducted on the alkali activation of fly ash (AAFA). In this singular procedure the grey powder (FA) is mixed with an alkaline solution (alkaline activators) and then cured at a moderate temperature to produce solid materials. The glassy constituent of the fly ash is transformed into a well-compacted cement. In previous research $(7,11,12)$ the main reaction product formed in AAFA was found to be an amorphous aluminosilicate gel with properties characteristic of a "zeolite precursor". According to research conducted by Davidovits (7) and Palomo (12), zeolite crystallisation may be the hypothetical final stage of alkali-activated fly ash. The short range order of the "zeolite precursor" consists of a 3-dimensional structure in which the Si occurs in a variety of environments (11, 12). Small amounts of some hydroxisodalite, herschelite and other crystalline zeolites have also been detected in such systems (11-14).

Whilst data on the development of mechanical strength in alkali-activated pastes and mortars may be found in the literature $(10,13,14,15)$, very few papers address the Portland cement-free manufacture of alkali-activated fly ash concrete.

The primary purpose of this paper, then, is to determine to what extent mix design factors (mix proportions, mixing procedure, curing time, curing temperature, nature and concentration of alkali activators, solution/fly ash ratio, etc.) affect the development of the compressive strength of AAFA concrete in the early stages of setting and hardening. In this regard, a comparative study of new activated fly ash and OPC concrete was conducted.

\section{EXPERIMENTAL}

\subsection{Materials}

Two types of Spanish type F fly ash and one commercial OPC (CEM I $52.5 R$ as described in Spanish Standard UNE 80-300/2000 IN) were used in the experiments. The chemical composition and specific surface of all materials are shown in Table 1. It may be readily deduced from 
deduce que los principales componentes de la ceniza volante son óxidos de sílice y alúmina, mientras que el cemento Portland consiste principalmente en óxidos de cal y sílice. Para la fabricación del hormigón se utilizaron dos tipos de áridos locales: árido silíceo grueso de tamaño comprendido entre 6 y $12 \mathrm{~mm}$ y arena silícea lavada de $0 / 5 \mathrm{~mm}$. Para preparar las diferentes disoluciones activadoras definidas en el plan de trabajo se utilizaron lentejas de hidróxido sódico y una disolución de silicato sódico $\left(\mathrm{SiO}_{2}=27,8 \%, \mathrm{Na}_{2} \mathrm{O}=8,2 \%\right.$ y $\mathrm{H}_{2} \mathrm{O}=64 \%$. En las Tablas 2 y 3 se presentan las principales variables de trabajo estudiadas, así como su rango, para los hormigones de AAFA y de OPC, respectivamente.

\subsection{Muestras}

Inicialmente durante 3 minutos se mezcla en la amasadora la ceniza con el árido en un caso y, en otro, el cemento con el árido; después se añade el líquido hidratante (disolución alcalina para las cenizas, agua para el cemento Portland), la mezcla resultante se amasa durante 5 minutos. La relación árido/material cementante/líquido se modificó de acuerdo a los datos mostrados en las Tablas 2 y 3 . La mezcla obtenida en cada caso se vierte en un molde cilíndrico de cartón no reciclable de $15 \mathrm{~cm}$ de diámetro por $30 \mathrm{~cm}$ de alto (ver Figura 1). El llenado se hace en tres capas, cada capa fue consolidada durante $15-20$ segundos con un vibrador. Para cada ensayo se prepararon tres probetas.

Inmediatamente después del moldeado, las muestras se introducen en una estufa donde se curan en condiciones de humedad relativa alta (> 90\%) a una temperatura y tiempo específicos (ver Tabla 2 para hormigones de AAFA y Tabla 3 para hormigones de OPC). Después del curado, las probetas fueron desmoldadas y guardadas a temperatura ambiente en el laboratorio (ver Figura 1) hasta que fueron rotas a compresión con una máquina de ensayos universal (SUPEZCAR 150T) como se describe en la norma española UNE-EN 12390-3: 2003.

El nivel de consistencia del hormigón fresco se determinó mediante su asentamiento en el cono de Abrams, según la norma EN 12350-2:2000. the table that the primary components of fly ash are silica and alumina, whilst Portland cement consists essentially of lime and silica. Two types of locally available aggregates were also used in the concrete mix: coarse siliceous aggregate ranging in size from 6 to $12 \mathrm{~mm}$ and 0/5- $\mathrm{mm}$ washed sand. Sodium hydroxide flakes and a sodium silicate solution $\left(\mathrm{SiO}_{2}=27.8 \%, \mathrm{Na}_{2} \mathrm{O}=8.2 \%\right.$ and $\mathrm{H}_{2} \mathrm{O}=64 \%$ ) were used to prepare the different concentrations of the solution defined in the test design. Tables 2 and 3 give the working variables studied and the range of variation for AAFA and OPC concrete, respectively.

\subsection{Specimen}

After fly ash and aggregates, on the one hand, and Portland cement and aggregates on the other were mixed in a pan mixer for 3 minutes, the hydrating liquid (alkali solution for fly ashes or water for portland cement) was added and the material mixed for a further 5 minutes. The values of this combined aggregate / binder / liquid ratio were modified as shown in Tables 2 and 3. The mixes obtained were cast, one layer at a time for a total of three, in $15 \mathrm{~cm}$ diameter $x 30 \mathrm{~cm}$ hight non-recycle cardboard cylinders (see Figure 1). Each layer was consolidated for 15-20 seconds with a vibrator. Three specimens were prepared for each test.

Immediately after casting, the samples were placed in an oven and cured at high relative humidity level under the specified time and temperature conditions (see Table 2 for AAFA concrete and Table 3 for OPC concrete). The specimens were de-moulded after curing and kept at room temperature in the laboratory (see Figure 1) until they were compression-tested in a universal testing machine (SUPEZCAR 150T) as described in Spanish standard UNE-EN 12390-3:2003.

The consistency of the fresh concrete was determined with a slump cone, pursuant to Spanish standard EN 12350-2:2000.

Tabla 1 / Table 1

Composición química del cemento y de las cenizas volantes Chemical composition of cement and fly ashes

\begin{tabular}{|l|c|c|c|c|c|c|c|c|c|c|c|}
\hline & ${ }_{1} \mathbf{L O I}$ & ${ }^{2} \mathbf{R I}$ & $\mathbf{S i O}_{\mathbf{2}}$ & $\mathbf{A l}_{\mathbf{2}} \mathbf{O}_{\mathbf{3}}$ & $\mathbf{F e}_{\mathbf{2}} \mathbf{O}_{\mathbf{3}}$ & $\mathbf{C a O}$ & $\mathbf{M g O}$ & $\mathbf{S O}_{\mathbf{3}}$ & $\mathbf{K}_{\mathbf{2}} \mathbf{O}$ & $\mathbf{N a}_{\mathbf{2}} \mathbf{O}$ & $\mathbf{3 S S}^{\mathbf{3} S}$ \\
\hline $\mathrm{CEM} 4$ & 1.64 & 0.76 & 19.33 & 5.66 & 2.66 & 63.07 & 0.36 & 3.38 & 1.88 & 0.14 & $459 \mathrm{~m}^{2} / \mathrm{kg}$ \\
\hline $\mathrm{FA} 1$ & 1.80 & 0.40 & 51.51 & 27.47 & 7.23 & 4.39 & 1.86 & 0.15 & 3.46 & 0.70 & $244 \mathrm{~m}^{2} / \mathrm{kg}$ \\
\hline $\mathrm{FA} 2$ & 3.59 & 0.32 & 53.09 & 24.80 & 8.01 & 2.44 & 1.94 & 0.23 & 3.78 & 0.73 & $360 \mathrm{~m}^{2} / \mathrm{kg}$ \\
\hline
\end{tabular}

1. LOI = Pérdida al fuego / Loss on ignition; 2 . RI = Residuo insoluble / Insoluble residue.

3. SS= Superficie específica / Specific surface; 4. CEM I 52,5 R UNE 80-300/2000 IN. 
Tabla 2 / Table 2

Variables de trabajo de los hormigones de AAFA Working variables for AAFA concrete

\begin{tabular}{|c|c|c|c|c|c|c|c|c|}
\hline \multirow{2}{*}{$\begin{array}{c}\text { Ensayo } \\
\text { Test } \\
\text { No. }\end{array}$} & \multicolumn{4}{|c|}{$\begin{array}{l}\text { Componentes sólidos } \\
\text { Solid components }\end{array}$} & \multicolumn{2}{|c|}{$\begin{array}{c}\text { Activador alcalino } \\
\text { Alkali activator }\end{array}$} & \multicolumn{2}{|c|}{$\begin{array}{c}\text { Condiciones de curado } \\
\text { Curing conditions }\end{array}$} \\
\hline & $\begin{array}{l}\text { Ceniza } \\
\text { Fly ash }\end{array}$ & $\begin{array}{c}\text { CAg } \\
\mathbf{S}^{1}\end{array}$ & $\begin{array}{c}\text { CAg }+S \\
\text { FA }^{2}\end{array}$ & $\begin{array}{l}\text { L/FA3 } \\
\text { (\%wt) }\end{array}$ & $\mathrm{NaOH}$ & $\begin{array}{l}\text { Silicato } \mathrm{Na} \\
\mathrm{Na} \text { silicate }\end{array}$ & $\begin{array}{c}\text { Tiempo } \\
\text { Time }\end{array}$ & $\begin{array}{l}\text { Temp. } \\
\left({ }^{\circ} \mathrm{C}\right)\end{array}$ \\
\hline 1 & FA1 & 1.26 & $5 / 1$ & 0.4 & $8 \mathrm{M}$ & - & $20 \mathrm{~h}$ & 85 \\
\hline 2 & FA1 & 1.26 & $4 / 1$ & 0.4 & $8 M$ & - & $20 \mathrm{~h}$ & 85 \\
\hline 3 & FA1 & 1.26 & $3 / 1$ & 0.4 & $8 M$ & - & $20 \mathrm{~h}$ & 85 \\
\hline 4 & FA1 & 1.26 & $4 / 1$ & 0.5 & $8 \mathrm{M}$ & - & $20 \mathrm{~h}$ & 85 \\
\hline 5 & FA1 & 1.26 & $4 / 1$ & 0.38 & $8 M$ & - & $20 \mathrm{~h}$ & 85 \\
\hline 6 & FA1 & 1.26 & $4 / 1$ & 0.38 & $7 \mathrm{M}$ & - & $20 \mathrm{~h}$ & 85 \\
\hline 7 & FA1 & 1.26 & $4 / 1$ & 0.38 & $9 \mathrm{M}$ & - & $20 \mathrm{~h}$ & 85 \\
\hline 8 & FA1 & 1.26 & $4 / 1$ & 0.4 & $8 M$ & - & $20 \mathrm{~h}$ & 40 \\
\hline 9 & FA1 & 1.26 & $4 / 1$ & 0.4 & $8 \mathrm{M}$ & - & $20 \mathrm{~h}$ & 120 \\
\hline 10 & FA1 & 1.26 & $4 / 1$ & 0.4 & $8 \mathrm{M}$ & - & $8 \mathrm{~h}$ & 85 \\
\hline 11 & FA1 & 1.26 & $4 / 1$ & 0.4 & $8 M$ & & $14 \mathrm{~h}$ & 85 \\
\hline 12 & FA2 & 1.26 & $5 / 1$ & 0.4 & $8 \mathrm{M}$ & - & $20 \mathrm{~h}$ & 85 \\
\hline 13 & FA2 & 1.26 & $4 / 1$ & 0.4 & $8 M$ & - & $20 \mathrm{~h}$ & 85 \\
\hline 14 & FA2 & 1.26 & $3 / 1$ & 0.4 & $8 \mathrm{M}$ & - & $20 \mathrm{~h}$ & 85 \\
\hline 15 & FA2 & 1.26 & $4 / 1$ & 0.5 & $8 \mathrm{M}$ & - & $20 \mathrm{~h}$ & 85 \\
\hline 16 & FA2 & 1.26 & $4 / 1$ & 0.38 & $8 M$ & - & $20 \mathrm{~h}$ & 85 \\
\hline 17 & FA2 & 1.26 & $4 / 1$ & 0.38 & $7 \mathrm{M}$ & - & $20 \mathrm{~h}$ & 85 \\
\hline 18 & FA2 & 1.26 & $4 / 1$ & 0.38 & $9 \mathrm{M}$ & - & $20 \mathrm{~h}$ & 85 \\
\hline 19 & FA2 & 1.26 & $4 / 1$ & 0.4 & $8 \mathrm{M}$ & - & $20 \mathrm{~h}$ & 40 \\
\hline 20 & $\mathrm{FA} 2$ & 1.26 & $4 / 1$ & 0.4 & $8 \mathrm{M}$ & - & $20 \mathrm{~h}$ & 120 \\
\hline 21 & FA2 & 1.26 & $4 / 1$ & 0.4 & $8 \mathrm{M}$ & - & $8 h$ & 85 \\
\hline 22 & FA2 & 1.26 & $4 / 1$ & 0.4 & $8 \mathrm{M}$ & & $14 \mathrm{~h}$ & 85 \\
\hline 23 & FA2 & 1.26 & $4 / 1$ & 0.45 & $12.5 \mathrm{M}$ & - & $20 \mathrm{~h}$ & 85 \\
\hline 24 & FA2 & 1.26 & $4 / 1$ & 0.45 & $95 \%(12.5 \mathrm{M})$ & $5 \%$ & $20 \mathrm{~h}$ & 85 \\
\hline 25 & FA2 & 1.26 & $4 / 1$ & 0.45 & $85 \%(12.5 \mathrm{M})$ & $15 \%$ & $20 \mathrm{~h}$ & 85 \\
\hline 26 & FA2 & 1.26 & $4 / 1$ & 0.45 & $75 \%(12.5 \mathrm{M})$ & $25 \%$ & $20 \mathrm{~h}$ & 85 \\
\hline 27 & FA2 & 1.26 & $4 / 1$ & 0.45 & $50 \%(12.5 \mathrm{M})$ & $50 \%$ & $20 \mathrm{~h}$ & 85 \\
\hline 28 & FA2 & 1.26 & $4 / 1$ & 0.45 & $25 \%(12.5 \mathrm{M})$ & $75 \%$ & $20 \mathrm{~h}$ & 85 \\
\hline
\end{tabular}

1. $\mathrm{CAg} / \mathrm{S}=$ Relación en peso de árido grueso $(6 / 12 \mathrm{~mm}) /$ arena lavada; Coarse aggregate $(6 / 12 \mathrm{~mm}) /$ washed sand $(0 / 5 \mathrm{~mm})$ ratio by weight.

2. $\mathrm{CAg}+\mathrm{S} / \mathrm{FA}=$ Relación en peso de árido grueso + arena / ceniza volante; Coarse aggregate + sand / fly ash ratio by weight.

3. L/FA = Relación líquido (disolución alcalina) / ceniza volante; Liquid (Alkali solution) / fly ash ratio.

Tabla 3 / Table 3

Variables de trabajo de los hormigones de OPC

Working variables for OPC concrete

\begin{tabular}{|c|c|c|c|c|c|c|}
\hline \multirow[t]{2}{*}{$\begin{array}{l}\text { Muestra } \\
\text { Sample }\end{array}$} & \multicolumn{4}{|c|}{ Componentes / Components } & \multicolumn{2}{|c|}{$\begin{array}{c}\text { Condiciones de curado } \\
\text { Curing conditions }\end{array}$} \\
\hline & $\begin{array}{l}\text { Cemento }^{1} \\
\text { Cement }^{1}\end{array}$ & CAg/S & $\mathrm{CAg}+\mathrm{S} / \mathrm{Cem}$ & W/Cem² & $\begin{array}{c}\text { Tiempo } \\
\text { Time }\end{array}$ & $\mathbf{T}\left({ }^{\circ} \mathrm{C}\right)$ \\
\hline Concr. 1 & CEM $52.5 \mathrm{R}$ & 1.26 & $4 / 1$ & 0.5 & $20 \mathrm{~h}$ & $22^{\circ} \mathrm{C}$ \\
\hline Concr. 2 & CEM $52.5 \mathrm{R}$ & 1.26 & $4 / 1$ & 0.5 & $20 \mathrm{~h}$ & $40^{\circ} \mathrm{C}$ \\
\hline
\end{tabular}

1. De acuerdo con la Instrucción del Hormigón Estructural Español, EHE, dosificación de $350 \mathrm{k} / \mathrm{m}^{3}$ (260 kg CEM I $52.5 \mathrm{R}+140 \mathrm{~kg}$ FA1) / Pursuant to the Spanish structural concrete code, EHE, dosage of $350 \mathrm{k} / \mathrm{m}^{3}$ (260 kg CEM I 52.5R + $140 \mathrm{~kg}$ FA1).

2. Estas muestras se incluyen un $0,84 \%$ en peso con respecto a la cantidad de cemento de aditivo (lignosulphonates) / These concrete samples include $0.84 \%$ wt. (of binder) the aditiv (lignosulphonates). 


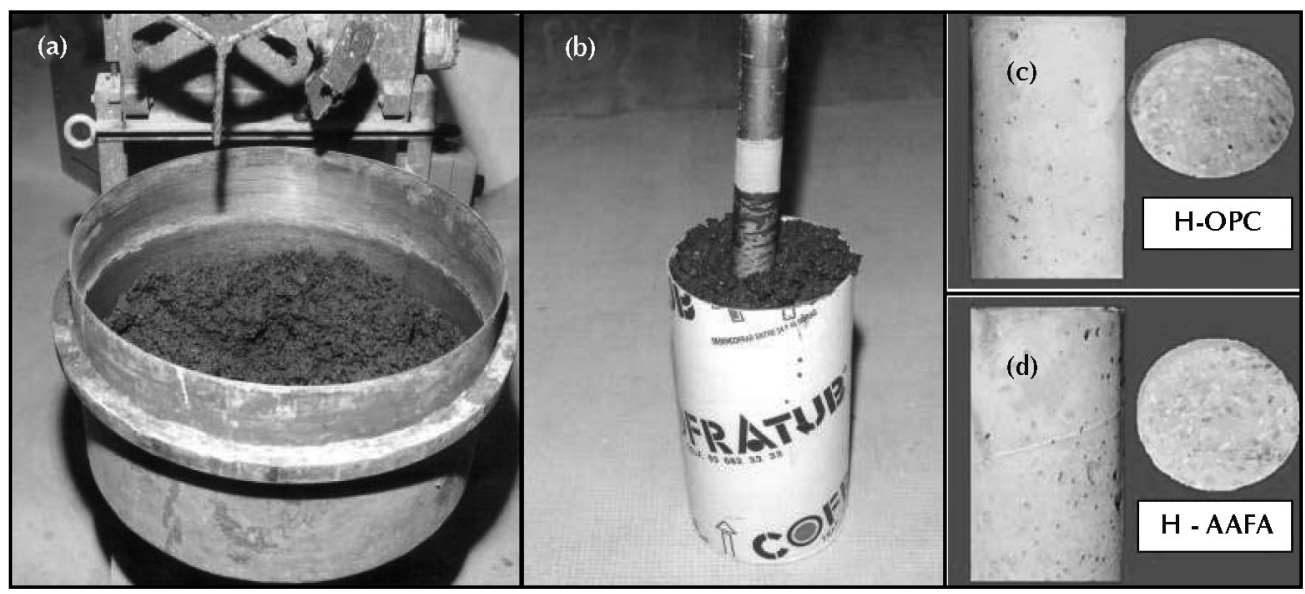

Figura 1. (a) Hormigón fresco de AAFA; (b) Cilindros de cartón no reciclables; (c) Hormigón de OPC endurecido; (d) Hormigón de AAFA endurecido.

Figure 1. (a) Fresh AAFA concrete; (b) Non-recycle cardboard cylinders; (c) Hardened OPC concrete; (d) Hardened AAFA concrete.

La caracterización microscópica se realizó mediante el estudio de muestras de hormigón impregnadas con resina epoxy, cortadas, pulidas y cubiertas con carbón. Para su caracterización por "Back-Scattered Electron Microscopy (BSEM)", se utilizó un microscopio electrónico de barrido JEOL JSM 5400 equipado con un detector de energía elecro-dispersada LINK-ISIS.

\section{RESULTADOS Y DISCUSIÓN}

Hoy en día nadie duda de que el hormigón de OPC es el material de construcción por excelencia. Son numerosos los artículos y libros publicados sobre sus propiedades, así como sobre su dosificación o sobre las condiciones de curado óptimas para obtener un buen material; es decir, un hormigón con propiedades mecánicas y durables que se adapten a las necesidades de la obra en donde se haya de colocar. Así, en términos generales existe un amplio consenso en la bibliografía (16-22) para considerar como variables claves de diseño a aquellas que afectan a la trabajabilidad del material en estado fresco, al desarrollo mecánico-resistente, a la durabilidad, etc. Las variables más importantes son: relación árido/material cementante, relación agua/material cementante; tiempo de curado, condiciones térmicas del curado, etc.

Consecuentemente, en este trabajo se presenta un estudio de cómo estas mismas variables afectan al desarrollo resistente y a la trabajabilidad de los hormigones de ceniza volante activada alcalinamante (exentos de cemento Portland). En este caso, por supuesto, además de las variables indicadas, se han considerado también otros dos parámetros de trabajo específicamente relacionados con el proceso de activación alcalina. Éstos son
Concrete samples were prepared for microscopic characterisation, i.e., impregnated with an epoxy resin, cut, polished and then coated with carbon. A JEOL JSM 5400 scanning electron microscope equipped with a solid state backscattering detector and a LINK-ISIS energy dispersive analyser was used for BSEM characterisation.

\section{RESULTS AND DISCUSION}

OPC is indisputably the construction material par excellence in today's world. Numerous books and papers have been published on optimum concrete properties, or the dosage and curing conditions to be met to produce concrete with the mechanical properties and durability required by the structure to be erected. There is, moreover, general consensus in the literature (16-22) on the key design variables that affect aspects such as workability of the fresh material, development of mechanical strength, durability and so on. These variables include the aggregate/binder ratio, water/binder ratio, curing time and temperature, etc.

This paper reports on a study of how these same variables affect the development of strength and the workability of (Portland cement-free) alkali-activated fly ash concrete. A previously prepared alkali solution is added to the mix instead of water in the manufacture of these new types of concrete. Therefore, in addition to the above variables, two other working parameters specifically related to alkali activation were considered, namely the 
la concentración y la naturaleza del activador alcalino utilizado, esto se debe a que en la elaboración de los nuevos hormigones en vez del agua de amasado se utiliza una disolución alcalina previamente preparada. Los resultados obtenidos se presentan a continuación.

\subsection{Relación árido grueso+arena / material cementante (CAg+S/FA)}

Se ha comprobado que hormigones con una dosificación muy alta de cemento, además de incrementar los costes de producción, pueden presentar importantes problemas de retracción y de durabilidad a largo plazo. En definitiva, y por todo ello, la mayor parte de las normativas vigentes para hormigones convencionales limitan el contenido de cemento a un máximo aproximado de 400 $\mathrm{kg} / \mathrm{m}^{3}$ (EHE Instrucción Española para el Hormigón Estructural). Por otro lado, hay que tener presente que en un hormigón de OPC cuando la relación "árido/material cementante" disminuye y la relación "agua/material cementante" permanece constante, entonces se incrementa el contenido total de líquido en la mezcla, aumentando consecuentemente la trabajabilidad del material en estado fresco.

Los efectos de modificar la relación "árido/material cementante" sobre las propiedades de los hormigones de ceniza volante activada son bastante similares a los efectos sobre los hormigones tradicionales de cemento Portland. En la Tabla 4 se muestran los resultados obtenidos al modificar dicha relación, manteniendo constante el resto de las variables de trabajo (ensayos número 1, 2 y 3 para la ceniza FA1 y 12,13 y 14 para la ceniza FA2, ver Tabla 2). Estos resultados indican que con independencia de trabajar con la ceniza FA1 o con la FA2, el incremento de la cantidad de ceniza lleva asociado un aumento de las resistencias mecánicas a compresión. Así, la resistencia a compresión que presenta la mezcla № 1 $(\mathrm{CAg}+\mathrm{S} / \mathrm{FA}=5 / 1)$ se corresponde con la de un hormigón convencional de alto contenido en cemento Portland $\left(360 \mathrm{k} / \mathrm{m}^{3}\right)$, mientras que en las mezclas con relación $4 / 1$ y $3 / 1$ (ensayos no 2 y 3, respectivamente), el contenido de ligante $\left(465 \mathrm{~kg} / \mathrm{m}^{3}\right.$ y $515 \mathrm{~kg} / \mathrm{m}^{3}$, respectivamante) es superior a lo habitualmente permitido por las normativas para hormigones normales (EHE, Instrucción Española para el Hormigón Estructural).

Un dato interesante a destacar es que en estos nuevos hormigones se observa también que, incrementando la cantidad de ceniza, se mejora notablemente la trabajabilidad del material en estado fresco, lo cual se refleja en un incremento de los valores suministrados por el ensayo del cono de Abrams (ver Tabla 4). Esto se debe fundamentalmente a que al elevar el contenido de ligante, simultáneamente aumenta la proporción de disolución alcalina que incorporamos a la mezcla, pasando de elaborar un concentration and nature of the alkali activator used. The results obtained are discussed below.

\subsection{Aggregate + sand / binder ratio $(C A g+S / F A)$}

Concrete with very high cement content has been shown not only to increase production costs, but to pose problems due to significant shrinkage and reduced durability. For these reasons, most of the existing building codes for conventional concrete limit the cement content to a maximum of approximately $400 \mathrm{~kg} / \mathrm{m}^{3}$ (EHE - Spanish structural concrete code). Moreover, in OPC concrete, when the aggregate/binder ratio declines and the water/binder ratio remains constant, the total liquid content in the mix rises, enhancing the workability of the fresh material.

Modifying the aggregate/binder ratio is found to have effects on activated fly ash concrete properties that are substantially similar to the effects observed in conventional Portland cement concrete when the aggregate/cement ratio is changed. Table 4 gives the results of modifying that ratio while maintaining all other working variables constant (tests 1, 2 and 3 for FA1 fly ash and 12, 13 and 14 for FA2 fly ash; see Table 2). These findings suggest that generally specimenes regardless of whether FA1 or FA2 fly ash is used, increases the amount of ash leads to higher compression strength. So the compressive strenght value of mix No. $1(C A g+S / F A=5 / 1)$, for instance, corresponds to a conventional concrete with a high Portland cement content $\left(360 \mathrm{k} / \mathrm{m}^{3}\right)$, whilst in the mixes with ratios of $4 / 1$ and $3 / 1$ (tests 2 and 3 , respectively), the binder content $\left(465 \mathrm{~kg} / \mathrm{m}^{3}\right.$ and $515 \mathrm{~kg} / \mathrm{m}^{3}$ respectively) is greater than usually allowed by concrete codes (EHE - Spanish structural concrete code).

One interesting finding in connection with these new types of concrete is that an increase in ash content also entails a considerable improvement in the workability of the fresh material, as can be seen from the slump test values (Abrams cone, see Table 4). This is primarily due to the fact that when the binder content is raised, the proportion of alkali solution added to the mix also rises, producing, instead of a stiff, nearly unworkable ( 0 slump) concrete, one that is substantially more workable 
hormigón seco, poco trabajable (cono 0), a unos hormigones entre secos y plásticos (cono de 2-3), bastante más trabajables. Aunque tampoco hay que despreciar el efecto de forma esférica de las partículas de ceniza que favorece la operación de mezcla de los distintos componentes del hormigón.

En la Figura 2 se observa el aspecto que presenta bajo el microscopio electrónico un hormigón de ceniza volante activada alcalinamente. En esta micrografía queda clara la coexistencia de partículas esféricas de ceniza intactas o parcialmente atacadas por la disolución (color gris claro) junto a la del material amorfo formado durante el proceso de activación alcalina (color gris más oscuro).

Comparando los resultados de resistencia mecánica a compresión obtenidos con los dos hormigones de ceniza objeto de estudio (ceniza FA1 y ceniza FA2; ensayos no $1,2,3$ y $12,13,14)$, se observa que las resistencias mecánicas a compresión son ligeramente mayores cuando la ceniza utilizada es la FA1. Esto, en principio, podría interpretarse como debido a la menor superficie específica de la ceniza FA1 $\left(244 \mathrm{~m}^{2} / \mathrm{kg}\right)$, que da lugar a mezclas
(2-3 cm slump). Nonetheless, the importance of the effect of the spherical shape of the ash particles, which provides for a good mix with the other concrete components, should not be overlooked in this regard.

Figure 2 shows the electron microscope image of a sample of alkali-activated fly ash concrete. The coexistence of intact and partially attacked fly ash spheres (light grey coloured) with the amorphous material formed during alkaline activation (dark grey coloured) can be clearly seen in this micrograph.

Comparing the compressive strength for the two types of fly ash concrete studied (ash FA1 and ash FA2; see tests 1, 2, 3 and 12, 13, 14), it is observed to be slightly higher for FA1. This may initially be interpreted to be due to the smaller specific surface of FA1 ash $\left(244 \mathrm{~m}^{2} / \mathrm{kg}\right)$, which produces more workable mixes that can be better consolidated in the cones. This finding, however, appears to contradict the results that would initially be anticipated

Tabla 4 / Table 4

Efecto de la dosificación CAg+S/FA

Effect of fly ash dosage, CAg+S/FA ratio

\begin{tabular}{|c|c|c|c|c|c|c|c|}
\hline $\begin{array}{c}\text { Ensayo } \\
\text { Test } \\
\text { No. }\end{array}$ & $\begin{array}{c}\text { CAg+S } \\
\text { /FA1 }\end{array}$ & $\begin{array}{c}\text { Rest. Compresion } \\
\text { Comp. Strength } \\
\text { MPa }\end{array}$ & $\begin{array}{c}\text { Cono } \\
\text { Slump } \\
\mathbf{( c m )}\end{array}$ & $\begin{array}{c}\text { Ensayo } \\
\text { Test } \\
\text { No }\end{array}$ & $\begin{array}{c}\text { CAg+ } \\
\text { S/FA1 }\end{array}$ & $\begin{array}{c}\text { Rest. Compresion } \\
\text { Comp. Strength } \\
\mathbf{M P a}\end{array}$ & $\begin{array}{c}\text { Cono } \\
\text { S/ump } \\
\mathbf{( c m}\end{array}$ \\
\hline 1 & $5 / 1$ & 44.5 & 0 & 12 & $5 / 1$ & 41.8 & 0.5 \\
\hline 2 & $4 / 1$ & 46.0 & 1 & 13 & $4 / 1$ & 45.8 & 1.5 \\
\hline 3 & $3 / 1$ & 50.1 & 3 & 14 & $3 / 1$ & 44.0 & 2.5 \\
\hline
\end{tabular}

1. $\mathrm{CAg}+\mathrm{S} / \mathrm{FA}=$ Relación en peso de árido grueso + arena/ceniza volante; Coarse aggregate + sand / fly ash ratio by weight.

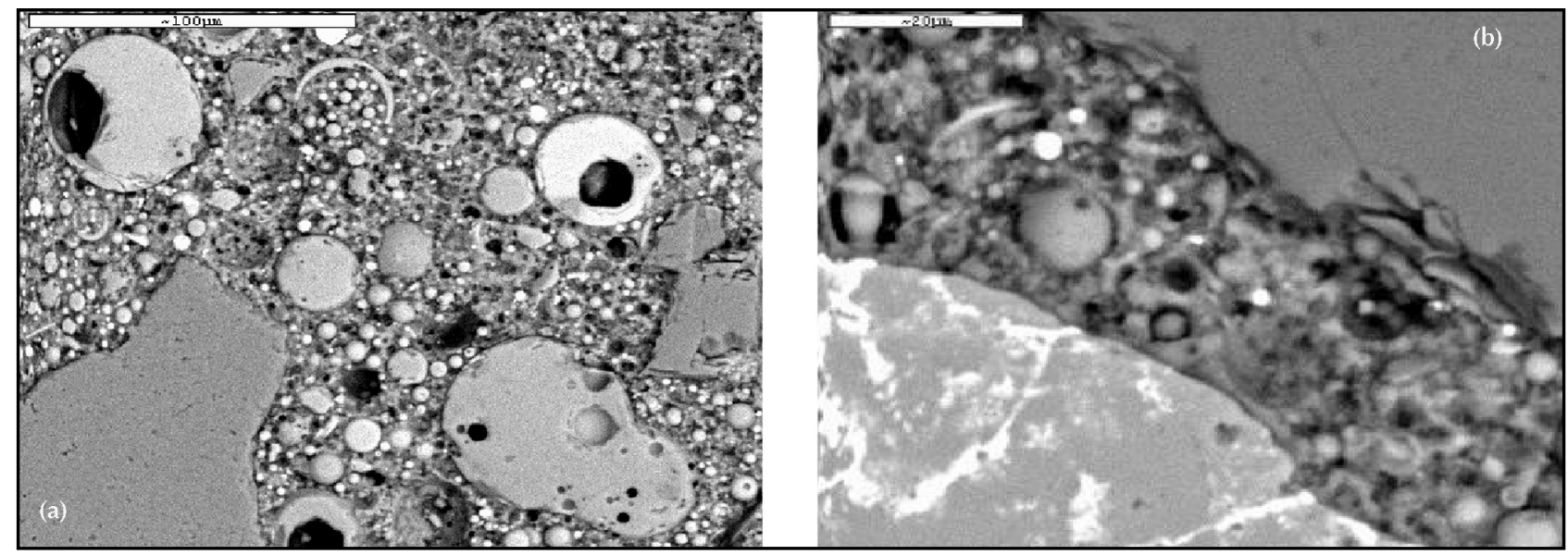

Figura 2. BSEM de hormigones de ceniza volante activada alcalinamante (a) $20 \mathrm{kv} \times 500$ (b) $20 \mathrm{kv} \times 1500$. Figure 2. BSEM of alkali activated fly ash concrete (a) $20 \mathrm{kv} \times 500$ (b) $20 \mathrm{kv} \times 1500$. 
más trabajables y que, por tanto, permiten una mejor compactación de las probetas. Aunque tambien es verdad que este hecho entraría en contradicción con los parámetros de reactividad intrínsecos a la naturaleza de las cenizas ante el ataque alcalino de éstas. Dichos parámetros, que estimularían el desarrollo de resistencias mecánicas, son fundamentalmente la mayor superficie específica y el mayor contenido de sílice reactivo (15); esto hacía esperar que la ceniza FA2 desarrollase mayores resitencias a compresión que la FA1.

Debe darse especial atención al hecho de que los hormigones alcalinos de ceniza volante con dosificaciones de ceniza superiores a $400 \mathrm{~kg} / \mathrm{m}^{3}$ no representan problema alguno, dada la muy escasa retracción que presentan estos materiales (23-26). Así, teniendo en cuenta los resultados de la Tabla 4, se decidió trabajar, en los experimentos sucesivos, con dosificaciones $C A g+S / F A=4 / 1$, ligeramente más altas a las empleadas en los hormigones tradicionales. Esta relación se considera suficiente para obtener un buen nivel de resistencias mecánicas y una buena trabajabilidad del material en estado fresco.

\subsection{Relación líquido / material cementante}

La relación agua/cemento constituye una de las variables fundamentales que condicionan las características de un hormigón tradicional. De esta relación depende la trabajabilidad del material en estado fresco, el desarrollo de resistencias mecánicas, el nivel de retracción por secado y también la permeabilidad que a su vez influye estrechamente en la durabilidad del material. Así, una mayor relación "líquido/material cementante" implica hormigones con menores resistencias mecánicas y más permeables, aunque más trabajables. La posibilidad de conciliar buena trabajabilidad con baja permeabilidad y elevado desarrollo mecánico-resistente ha sido lo que ha hecho que la industria de la construcción haya desarrollado numerosos aditivos químicos que tienen la propiedad de mantener la trabajabilidad de las mezclas reduciendo su proporción "líquido/material cementante".

En los hormigones de ceniza volante activada, el papel que juega la relación "líquido/material cementante" es muy similar al que juega en los hormigones tradicionales. En la Figura 3 se muestra la evolución de las resistencias mecánicas a compresión de los hormigones elaborados por activación alcalina de las cenizas FA1 y FA2, al modificar la relación "disolución alcalina/ceniza" $(L / F A=0,38 ; 0,4$ y 0,5, ensayos no 2, 4, 5 y 13, 1516 , ver Tabla 2). Los resultados indican que las situaciones más favorables se dan para valores de "L/FA" de 0,4 y de 0,5 . Para relaciones más bajas, se pierde mucha plasticidad haciendo que los hormigones se compacten mal; esto incide negativamente en la posterior evolución de las resistencias mecánicas. No obstante, valores muy on the basis of the reactivity parameters intrinsic to the nature of the fly ash. Indeed, the characteristics that favour the development of mechanical strength when the ash comes under alkali attack are primarily greater specific area and a higher reactive silica content (15); on these grounds, FA 2 would be expected to develop greater compressive strength than FA 1.

Particular attention should be drawn to the fact that in the case of alkali-activated fly ash concrete, working with ash doses of over $400 \mathrm{~kg} / \mathrm{m}^{3}$ poses no problem whatsoever because of the scant shrinkage observed in these materials (23-26). Therefore, on the grounds of the results shown in Table 4, a ratio of $C A g+S / F A=4 / 1$ was used in the different experiments throughout the study, for a slightly higher binder content than in traditional concrete. This ratio is regarded to provide for both high mechanical strength and good workability of the fresh material.

\subsection{Liquid / binder ratio}

The water/cement ratio is one of the key variables that determines the characteristics of traditional concrete. Fresh concrete workability, the development of mechanical strength, shrinkage and permeability all depend on this ratio, whilst permeability in turn is closely related to durability. Hence, a higher "liquid/binder" ratio yields a lower strength and more permeable although also more workable concrete. The need to combine good workability with low permeability and high mechanical strength has led the construction industry to develop any number of chemical admixtures that increase slump while reducing the "liquid/binder" ratio.

In activated fly ash concrete the role played by the "liquid/binder" ratio is very similar to its role in traditional concrete. Figure 3 shows compressive strength patterns for concrete made from FA 1 and FA 2 alkali-activated fly ash when the "liquid (alkali solution) / fly ash" ratio is raised $(L / F A=0.38 ; 0.4$ and 0.5 tests $2,4,5$ and 13, 15 16, see Table 2). The results appear to indicate that the optimum L/FA values lie between 0.4 and 0.5 . Lower ratios forfeit plasticity, and as a result the concrete cannot be properly consolidated, which has a negative impact on the subsequent development of mechanical strength. However, very high "L/FA" values, while substantially improving fresh material workability, also generate more porous concrete, with a concomitant 
altos de la relación "L/FA", si bien ayudan a incrementar notablemente la trabajabilidad del material en estado fresco, también son responsables de generar hormigones más porosos, aunque con un mayor riesgo de segregación y con menores resistencias a compresión.

Además hay que indicar que las diferencias encontradas en el comportamiento mecánico de los hormigones de ceniza FA1 y los de ceniza FA2 se interpretan como debidos a las propiedades intrínsecas de las propias cenizas utilizadas (tamaño de partícula, contenido de sílice reactiva, etc.) (15), tal y como se comentó en el anterior apartado.

En estos sistemas fuertemente alcalinos, el uso de los aditivos comerciales que mejoran la trabajabilidad del material en estado fresco no da los mismos resultados que en los hormigones de OPC. Esto se debe a que la mayor parte de los aditivos que hay en el mercado no son estables en estos medios tan fuertemente básicos y, además, a que estos productos están mayoritariamente diseñados para actuar sobre el calcio del cemento por medio de la formación de complejos (16). El Ca es un elemento minoritario en las cenizas tipo $\mathrm{F}$ usadas en los nuevos hormigones alcalinos. No obstante, nuestra propia experiencia nos ha demostrado que los aditivos de naturaleza sulfonada pueden tener efectos positivos en estos sistemas $(27,28)$.

Los microanálisis realizados en las muestras de la Figura 2 , que se corresponden con el ensayo no 2, confirman que el principal producto de reacción es un gel de aluminosilicato sódico con una relación $\mathrm{Si} / \mathrm{Al}$ entre $1,7-1,8$ y una relación $\mathrm{Na} / \mathrm{Al}$ entre 0,6-0,9. Estos resultados están de acuerdo con trabajos previos $(12,14,29,30)$. higher risk of segregation and lower compression strength.

At the same time, sight should not be lost of the fact that the differences found in the mechanical performance of concrete made from FA1 and FA2 are interpreted to be due to the intrinsic properties of the fly ash used (particle size, relative silica content, etc.) (15), as discussed in the preceding section.

In these highly alkaline environments, the use of commercial admixtures to improve fresh concrete workability do not render the same results as in OPC concrete. This is due to the fact that most commercial admixtures are unstable in such basic media and that most of these products are designed to act on the calcium in the cement by forming complexes (16). Yet Ca is a minority element in the $F$ type ash used in new alkaline concrete. Nonetheless, the authors' own experience has shown that sulphonated admixtures many have beneficial effects on such systems $(27,28)$.

Micro-analysis carried out on sample no 2, showed at Figure 2, confirmed that the main reaction product is a sodium aluminosilicate gel with a Si/Al ratio of 1.7-1.8 and a $\mathrm{Na} / \mathrm{Al}$ ratio of $0.6-0.9$. These results agree with previous investigation $(12,14,29,30)$.

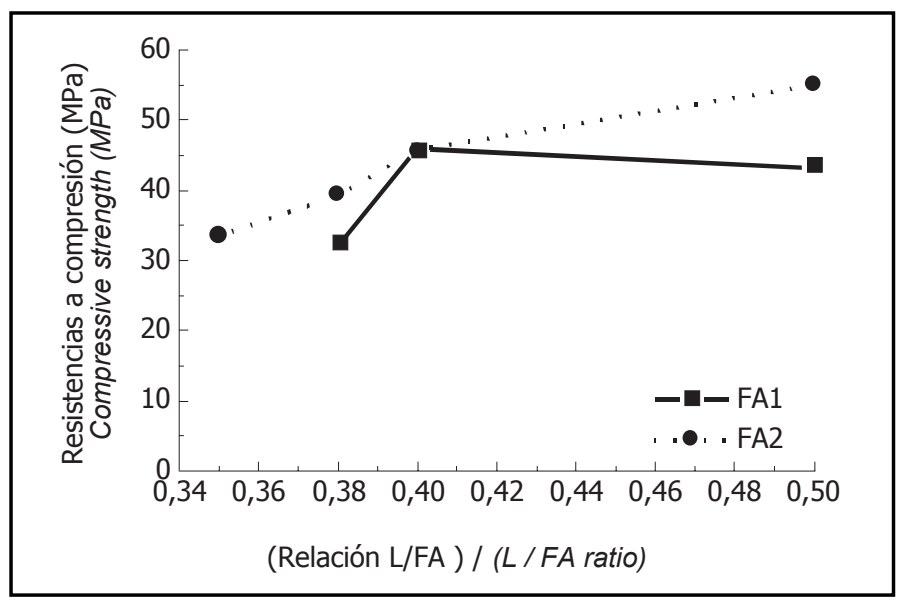

Figura 3. Efecto de la relación L/FA en el desarrollo de resistencias a compresión en hormigones de ceniza volante activada alcalinamente.

Figure 3. Effect of L/FA ratio on the development of compressive strength in akali-activated fly ash concrete. 
Es necesario señalar que en estos sistemas alcalinos, un incremento elevado de la relación "L/FA" implica un mayor aporte de alkali, que al no ser fijado en su totalidad por los productos de reacción podría dar lugar a la aparición de eflorescencias. También señalar que elevados ratios "L/FA" implican un mayor consumo de activador lo cual conlleva a su vez un incremento en los costes de producción ya que la disolución alcalina es el componente más caro de estos hormigones.

\subsection{Temperatura y tiempo de curado}

Es bien conocido que cuando el hormigón de OPC es curado térmicamente se acorta el tiempo de fraguado y se incrementan las resistencias mecánicas iniciales (17). Este hecho permite, por ejemplo, incrementar los ritmos de producción y abaratar los costes en la industria de los prefabricados de hormigón.

No obstante, el curado térmico del hormigón de cemento Portland suele tener algunos efectos adversos sobre el comportamiento resistente y durable del material: el incremento de la temperatura de curado favorece, por supuesto, una rápida velocidad de hidratación del cemento, que da como resultado un mayor desarrollo mecánico inicial, pero también una mayor concentración de productos de reacción sobre las partículas inicialmente hidratadas (18). Este hecho retardaría la hidratación posterior de esas mismas partículas, lo cual afecta negativamente al desarrollo de resistencias mecánicas a medio y largo plazo. En periodos estivales este fenómeno se observa con cierta frecuencia.

Otro problema que puede aparecer en el hormigón de cemento Portland como consecuencia de su curado térmico (especialmente si la temperatura de curado sobrepasa los $50-60{ }^{\circ} \mathrm{C}$ ) es el denominado fenómeno DEF (Delayed Ettringite Formation). En opinión de un gran número de autores (19-22), este fenómeno ha de considerarse como un tipo de ataque interno de sulfatos que conduce a la expansión de la pasta y que genera la aparición de fisuras periféricas alrededor de los áridos.

Todos estos problemas relacionados con el curado térmico de los hormigones de OPC hacen que la temperatura de curado se limite generalmente a un máximo de $50{ }^{\circ} \mathrm{C}$, lo cual tiene una incidencia especial en la industria de los prefabricados. Sin embargo, estos problemas no afectan a los hormigones de ceniza volante activada alcalinamente, lo cual ha de considerarse como una muy interesante característica de estos nuevos hormigones.

En la Figura 4(a) se muestra el efecto del incremento de la temperatura de curado $\left(40{ }^{\circ} \mathrm{C}, 85^{\circ} \mathrm{C}\right.$ y $120^{\circ} \mathrm{C}$ ) sobre la evolución mecánica resistente de los hormigones de AAFA (ensayos no 2, 8, 9, y 13, 19, 20, ver Tabla 2). Los
It should be noted that in these alkaline systems, a large increase in the L/FA ratio also entails more alkali, not all of which is fixed by the reaction product (see Figure 2); this situation may give rise to efflorescence. Attention is also drawn to the fact that high "L/FA" ratios involve the use of larger amounts of activator and therefore higher production costs, since alkali dissolution is the costliest stage in the manufacture of this type of concrete.

\subsection{Temperature and time of curing}

It is a generally accepted fact that when OPC concrete is thermally cured, the setting time is shortened and initial mechanical strength enhanced (17). This makes it possible, for instance, to raise output rates and lower the cost of pre-cast concrete production.

Nonetheless, the thermal curing of Portland cement concrete usually has adverse effects on material performance, in terms of both strength and durability: higher curing temperatures naturally expedite cement hydration, resulting in the development of greater initial strength, but this process also gives rise to a higher concentration of reaction products on the initially hydrated particles (18). As a result, the subsequent hydration of these same particles is actually retarded, which has an adverse effect on medium and long-term mechanical strength. This phenomenon is often observed in the summer months.

Another problem that may appear in Portland cement concrete as a result of thermal curing (particularly if the temperature rises above $50-60^{\circ} \mathrm{C}$ ) is so-called DEF phenomenon (Delayed Ettringite Formation). Many authors (19-22) believe that this phenomenon must be regarded to be a type of internal sulphate attack that leads to paste expansion and the appearance of peripheral cracking around the aggregate.

As a result of all these thermal curing-related problems in OPC concrete, the curing temperature is generally limited to a maximum of $50^{\circ} \mathrm{C}$, a restriction that is especially relevant for the pre-cast industry. The fact that alkali-activated fly ash concrete is not affected by these problems is yet another very promising feature of this new type of concrete.

Figure 4(a) shows the effect of increasing curing temperature $\left(40^{\circ} \mathrm{C}, 85^{\circ} \mathrm{C}\right.$ and $\left.120^{\circ} \mathrm{C}\right)$ on the development of AAFA concrete mechanical strength (tests 2, 8, 9, and 13, 19, 20, see Table 2). The results obtained show that 
resultados obtenidos demuestran que el aumento de la temperatura de curado incrementa notablemente los valores de resistencia a compresión de estos hormigones, siendo este efecto independiente del tipo de ceniza utilizada.

A $40^{\circ} \mathrm{C}$ los valores de resistencias a compresión tras 20 horas de curado son muy bajos. Sin embargo, cuando se alcanzan los $85^{\circ} \mathrm{C}$, la resistencia a compresión se eleva notablemente, obteniéndose valores sobre $45 \mathrm{MPa}$ a las 20 horas de curado. Estos valores son iguales o superiores a los obtenidos con hormigones normales de OPC, tras 28 días de curado convencional. Incrementando la temperatura hasta alcanzar los $120^{\circ} \mathrm{C}$, las resistencias mecánicas a 20 horas pueden llegar hasta los $60 \mathrm{MPa}$. Estos resultados son similares a los registrados en la bibliografía para pastas y morteros de ceniza volante activada alcalinamente $(10,14,23-25)$.

En la Figura 4(b) se muestra la influencia del tiempo de curado sobre la evolución de las resistencias a compresión de los hormigones AAFA (ensayos no 2, 10, 11, y $13,21,22$, ver Tabla 2). Entre un curado de 8 horas y otro de 14 horas, las resistencias a compresión se incrementan desde 28-30 MPa a 38-40 MPa (25\%), mientras que entre 14 y 20 horas este incremento se sitúa en porcentaje sensiblemente menor (10\%). Estos resultados están de acuerdo con los obtenidos por otros autores $(13,26)$, que indican que el incremento de resistencias a compresión después de las primeras 48 horas de curado se produce muy lentamente.

La ganancia de resistencias a compresión en hormigones de ceniza volante activada en función de la temperatura y del tiempo de curado se ajusta, por tanto, a un comportamiento exponencial. El efecto de ambas variables es muy importante en los momentos iniciales, pero pierde relevancia con el tiempo. Además, tiempo y temperatura the compressive strength value of this type of concrete rises substantially with curing temperature, regardless of the type of fly ash used.

At $40{ }^{\circ} \mathrm{C}$ the 20-hour compressive strength values are very low. When the temperature is raised to $85{ }^{\circ} \mathrm{C}$, however, compressive strength grows substantially, reaching values of up to $45 \mathrm{MPa}$ after 20 hours. Such values are equal to or even greater than the figures observed for normal OPC concrete after 28 days of conventional curing. When the temperature is increased to $120^{\circ} \mathrm{C}$, 20-hour strength values of up to $60 \mathrm{MPa}$ can be attained. These findings are similar to the results reported in the literature for alkali-activated fly ash paste and mortar $(10,14,23-25)$.

The effect of curing time on the development of compression strength in AAFA concrete is shown in Figure 4(b) (tests 2, 10, 11, and 13, 21, 22, see Table 2). Compressive strength rises from 28-30 $\mathrm{MPa}$ to 38-40 MPa (25\%) between 8 and 14 hours of curing time, whilst the rate of increase is considerably smaller $(10 \%)$ in the 14 to 20-hour interval. These results concur with the findings of other authors $(13,26)$, who report that compression strength climbs very slowly after the first 48 hours.

The compression strength gain in activated fly ash concrete with temperature and curing time is found to fit an exponential curve, i.e., both variables have a very significant initial effect which tapers over time. Moreover, temperature and time are inversely related as far as their impact on the development of mechanical strength is

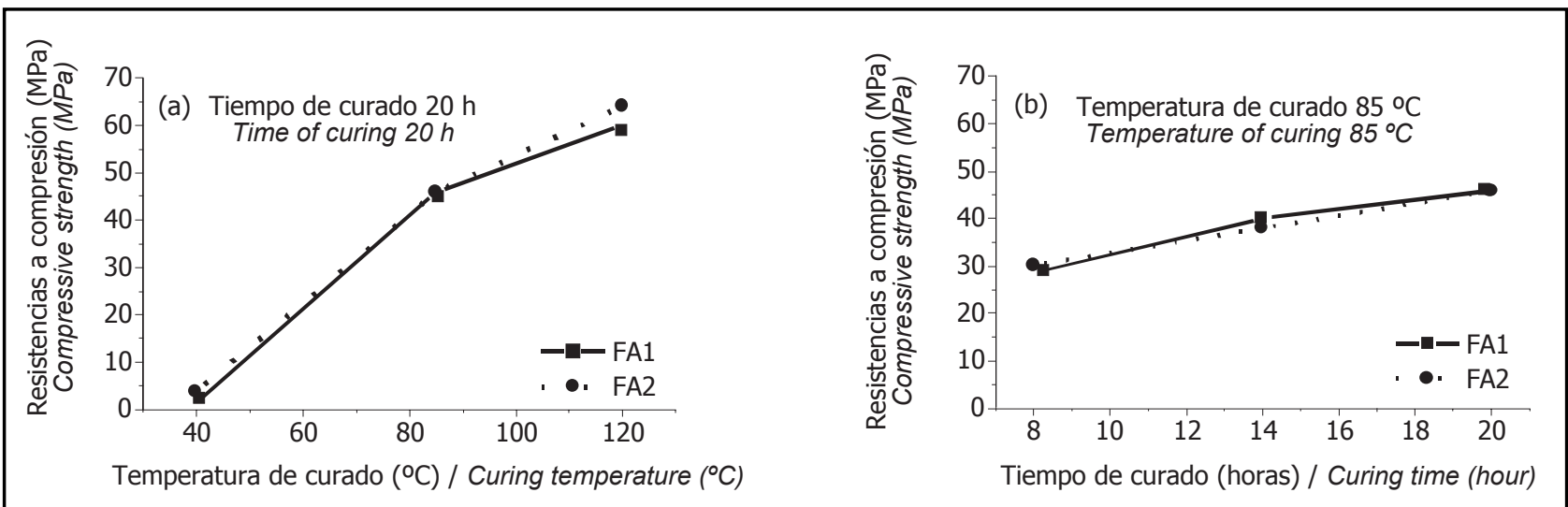

Figura 4. Efecto de (a) temperatura de curado (b) tiempo de curado en el desarrollo de resistencias mecánicas de hormigones de AAFA. Figure 4. Effect of (a) curing temperature and (b) curing time on the development of mechanical strength in AAFA concrete. 
son dos variables inversamente relacionadas entre sí en lo que se refiere a su efecto sobre la evolución mecánica resistente del material: a mayor temperatura, menor tiempo de curado necesario para alcanzar valores similares de resistencia mecánica, y viceversa.

En realidad, la temperatura y el tiempo de curado son variables muy relacionadas con la cinética del proceso. Si bien el principal producto de reacción que se forma en la activación alcalina de cenizas volantes es un gel de aluminosilicato alcalino, la relación Si/Al de dicho gel cambia con la temperatura y con el tiempo de curado. Estudios previos $(12,27)$ han demostrado que a bajas temperaturas de curado, la velocidad de reacción es lenta y la cantidad de aluminio incorporado al gel es alta. Mientras que un incremento del tiempo de curado implica un incremento del contenido de sílice del producto final, al tiempo que produce un aumento de las propiedades mecánicas del material. Es decir, que un adecuado control del tiempo y de la temperatura de curado puede permitir la obtención de un gel de aluminosilicato alcalino con diferentes relaciones $\mathrm{Si} / \mathrm{Al}$, lo cual a su vez afectaría al desarrollo de propiedades mecánicas y durables.

En la Figura 5 se presenta la evolución en el tiempo de las resistencias mecánicas de un hormigón de ceniza volante curado $20 \mathrm{~h}$ a $85^{\circ} \mathrm{C}$; y se compara con los resultados obtenidos para un hormigón de cemento Portland tradicional (Concr. 1 y Concr. 2) (ver Tabla 3). A través de las curvas de la Figura 5 se observa que los hormigones de ceniza volante activada presentan una rápida ganancia de resistencias a compresión alcanzando los 45,8 MPa a un día. Esta ganancia de resistencias mecánicas es muy rápida porque la reacción química de polimerización del gel alcalino es una reacción muy rápida $(7,12)$. No obstante, en concerned: the higher the temperature the shorter the curing time required to reach similar mechanical strength values and vice-versa.

Actually, curing temperature and time are variables closely related to process kinetics. Whilst the chief reaction product of the alkali-activation of fly ash is an alkaline aluminosilicate gel, the Si/Al ratio in that gel changes with curing temperature and time. Prior studies $(12,27)$ have shown that at low curing temperatures, the reaction speed is slow and the aluminium content in the gel is high. Longer curing times, in turn, lead to lower aluminium content in the final product and enhanced mechanical strength. In other words, aluminosilicate gels with different Si/Al ratios, which ultimately affect the development of mechanical strength and durability, can be produced by controlling curing time and temperature.

Figure 5 shows the development of mechanical strength in a fly ash concrete cured for $20 \mathrm{~h}$ at $85^{\circ} \mathrm{C}$ and the comparison of these results to the findings for traditional Portland cement concrete (Concr. 1 and Concr. 2) (See Table 3). It will be noted from the curves in Figure 5 that activated fly ash concrete gains compression strength very quickly, reaching a value of 45.8 MPa after the first day. Mechanical strength rises very quickly because the polymerisation reaction in the alkaline gel takes place very rapidly (7-12). Contrary to other reports $(13,26)$, however, as Figure 5 shows,

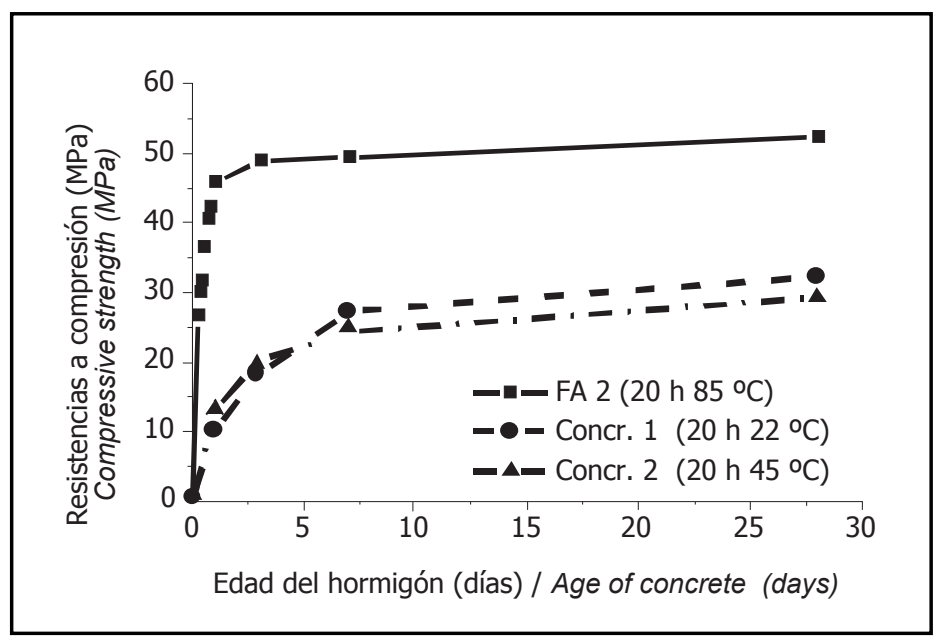

Figura 5. Resistencias a compresión a diferentes edades.

Figure 5. Compressive strength at different ages. 
contra de lo indicado por otros autores $(13,26)$, las resistencias mecánicas continúan aumentando con el tiempo porque, aunque de forma más lenta tal y como se observa en la Figura 5, la reacción de activación sigue progresando.

\subsection{Concentración y naturaleza del activador alcalino}

En la Figura 6 se presenta la evolución de las resistencias mecánicas a compresión cuando se modifica la concentración de la disolución de $\mathrm{NaOH}$ ulizada como activador alcalino (ensayos no 2, 6, 7, y 16, 17, 18, ver Tabla 2).

Estos resultados indican que manteniendo constantes el resto de las variables de trabajo, las resistencias mecánicas de los hormigones de ceniza activada aumentan al incrementar la concentración del activador. En realidad el incremento de la concentración del activador implica elevar el pH del medio y aumentar el contenido de $\mathrm{Na}_{2} \mathrm{O}$ en el sistema. Todo ello favorece la disolución de las partículas de ceniza original y la precipitación del silicoaluminato alcalino tipo gel (14), compuesto responsable de las propiedades cementantes de estos materiales y por lo tanto responsable del desarrollo mecánico resistente.

Sin embargo, de estos resultados no debiera extraerse la conclusión errónea de que todo aumento en la concentración alcalina del sistema induce un incremento de resistencias mecánicas. Si bien es verdad que los datos e investigaciones existentes sobre hormigones alcalinos son todavía muy escasos; los autores del presente trabajo disponen de un gran número de resultados en torno al comportamiento mecánico de morteros alcalinos y de la influencia de la concentración de álcali en dicho comportamiento. Así, de la Figura 7 se desprende la enorme influencia que ejerce, sobre el incremento de las resistencias a compresión de los morteros, proporciones de $\mathrm{Na}_{2} \mathrm{O}$ en torno al 7\%. Valores inferiores al 6\% apenas generan la fuerza iónica necesaria para producir el gel aluminosilicico de carácter cementante. $Y$ valores por encima del $8 \%$ ya no aportan resistencias adicionales.

Con respecto al tipo o naturaleza del activador alcalino, también se determinaron en la presente investigación las variaciones de las resistencias mecánicas de los hormigones en función de la proporción de silicatos solubles presentes en la disolución activadora. La decisión de incorporar silicatos solubles a la disolución activadora se tomó porque en trabajos anteriores se había comprobado que la presencia de estos podía favorecer notablemente el desarrollo de las resistencias mecánicas $(5,10$, 13). Los resultados obtenidos se muestran en la Tabla 5.

De estos resultados se deduce, en contra de lo esperado inicialmente, que el incremento del porcentaje de waterglass en la disolución activadora es responsable de la reducción de las resistencias a compresión de los hormigones. Este mechanical strength continues to increase over time, albeit more slowly.

\subsection{Concentration and nature of alkaline activator}

Figure 6 contains a curve that describes the development of compression strength when the concentration of the $\mathrm{NaOH}$ solution used as an alkaline activator is varied (tests 2, 6, 7 and 16, 17, 18, see Table 2).

The results suggest that, under these conditions, all other working variables being equal, the mechanical strength of activated fly ash rises at higher activator concentration. In fact, raising activator concentration entails increasing the $\mathrm{pH}$ oh the system as well as its $\mathrm{Na}_{2} \mathrm{O}$. Both these factors favour the dissolution of the original ash particles and the precipitation of the alkaline silicoluminate (14); this compound is responsible for the cementitious properties of these materials and therefore for the development of mechanical strength.

These findings should not, however, lead to the erroneous conclusion that any increase in the alkaline concentration of the system improves mechanical strength. Indeed, the data from research on alkaline concrete are still very scant; nonetheless, the authors of the present paper have a larger store of results relating the mechanical performance of alkaline mortars and the effect of alkali concentration on their performance. $\mathrm{A} \mathrm{Na} \mathrm{Na}_{2} \mathrm{O}$ content in the activating solution of the order of $7 \%$ has a visible impact on the increase in mortar strength, as may be clearly deduced from Figure 7. Values of under $6 \%$ rarely generate the ionic force required to produce the cementitious aluminoscilicate gel, whilst no additional strength is recorded at values of over $8 \%$.

The variations in concrete mechanical strength were also determined when the proportion of soluble silicates present in the activating solution was raised or lowered to judge the effect of the type or nature of the alkaline activator. The decision to include soluble silicates in the activating solution was taken because, in previous studies, they had been found to provide a considerable improvement in the development of mechanical resistance $(5,10,13)$. The results are given in Table 5.

It may be deduced from these results that, contrary to what was initially anticipated, a rise in the waterglass content in the activating solution leads to a reduction in the compression strength of this type of concrete. This 


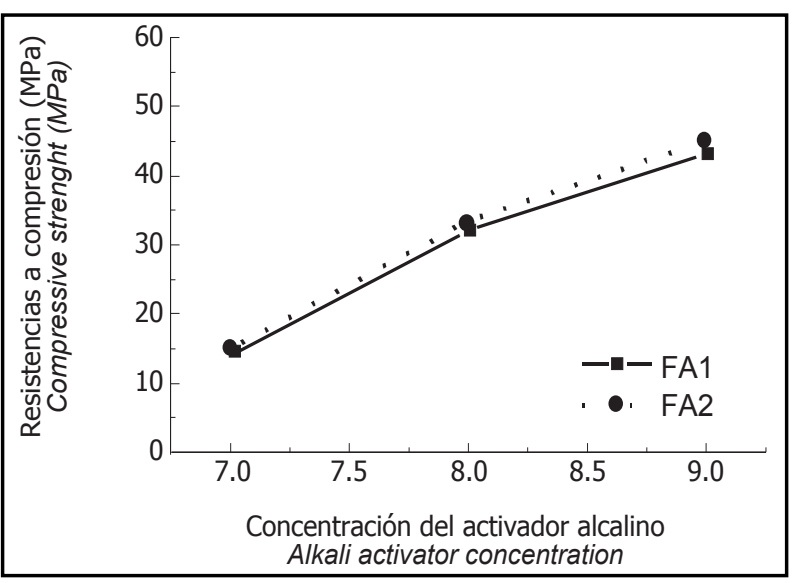

Figura 6. Efecto de la concentración del activador en las resistencias mecánicas de hormigones de AAFA.

Figure 6. Effect of activator concentration on AAFA concrete mechanical strength.

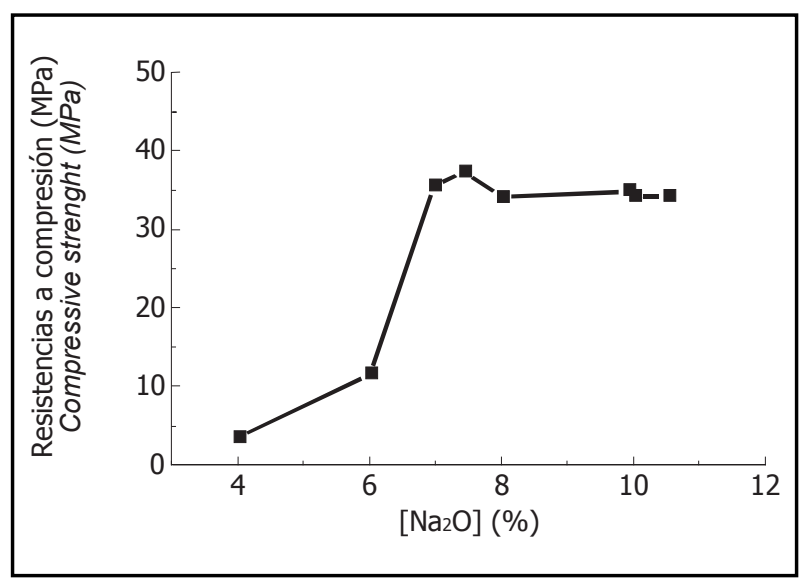

Figura 7. Efecto de la concentración del activador sobre las resitencias mecánicas en AAFA morteros.

Figure 7. Effect of activator concentration on mechanical strength in AAFA mortar.

Tabla 5 / Table 5

Efecto de la naturaleza del activador alcalino sobre las resistencias a compresión Effect of nature of alkaline activator on compressive strength

\begin{tabular}{|c|c|c|c|c|}
\hline $\begin{array}{c}\text { Ensayo / Test } \\
\text { No. }\end{array}$ & 1L/FA & Activador / Activator & Cono / Slump (cm) & $\begin{array}{c}\text { Resist. Compresión } \\
\text { Comp. strength (MPa) }\end{array}$ \\
\hline 23 & 0.45 & $100 \% \mathrm{NaOH} 12.5 \mathrm{M}$ & 3 & 98.60 \\
24 & 0.45 & $95 \% \mathrm{NaOH} 12.5 \mathrm{M}+5 \% \mathrm{wt}{ }^{2}$ & 5 & 49.00 \\
25 & 0.45 & $85 \% \mathrm{NaOH} 12.5 \mathrm{M}+15 \mathrm{wt}$ & 9 & 32.50 \\
26 & 0.45 & $75 \% \mathrm{NaOH} 12.5 \mathrm{M}+25 \% \mathrm{wt}$ & 10 & 26.80 \\
27 & 0.45 & $50 \% \mathrm{NaOH} 12.5+50 \% \mathrm{wt}$ & 15 & 13.40 \\
28 & 0.45 & $25 \% \mathrm{NaOH} 12.5 \mathrm{M}+75 \% \mathrm{wt}$ & $>15$ & \\
\hline
\end{tabular}

1. $L / F A=$ Relación líquido/ceniza volante en peso / liquit/fly ash ratio in weit.

2. $\mathrm{wt}=$ silicato sódico / Sodium silicate $\left(\mathrm{SiO}_{2}=27.8 \%, \mathrm{Na}_{2} \mathrm{O}=8.2 \%\right.$ and $\left.\mathrm{H}_{2} \mathrm{O}=64 \%\right)$.

hecho lo hemos relacionado con los problemas de reología que presentaban estos sistemas (difícil trabajabilidad acompañada de un rápido endurecimiento): inicialmente las mezclas están muy plásticas e incluso cuanto mayor es el contenido de waterglass mayor es su plasticidad. No obstante, a la vez que se incrementa la plasticidad se acorta el tiempo de fraguado, haciendo que en algunos casos fuera practicamente implosible realizar la compactación.

Las causas que conducen a este rápido endurecimiento, no están aún claras. Problablemente son varios los factores que intervienen en el proceso. Por un lado se trata de pastas muy densas lo cual por si justifica una pérdida de trabajabilidad. Además la presencia de iones silicato disueltos en la disolución favorece un rápido desplazamiento de las reacciones químicas iniciales. Tambien hay que destacar que estas mezclas, aunque se realizan a temperatura ambiente, desprenden inicialmente una gran cantidad de calor lo cual favorece que una parte del agua de mezcla se pierda por evaporación. may be attributed to the rheological and setting characteristics posed by such systems: the mixes are initially very plastic and, in principle, the higher the waterglass content the higher the plasticity. But as plasticity increases, setting time shortens, rendering consolidation virtually impossible.

The reasons for this speedy hardening are not yet clear. Various factors are very likely involved in the process. Firstly, these pastes are very dense, which in itself justifies a certain loss of workability. Moreover, the presence of silica ions in the solution favours speedy evolution of the initial chemical reactions. It should also be noted that, although conducted at room temperature, the mixing process initially releases heat, which entails evaporation of some of the water in the mix. 
Finalmente hay que señalar que a estos problemas de mala trabajabilidad y compactación se une un menor grado de reacción de los materiales cuando se incrementa el contenido de waterglass en el sistema. Este incremento de silicatos se realiza en detrimento del $\mathrm{NaOH}$, lo que hace disminuir el contenido de iones $\mathrm{OH}$ del medio y por ello el $\mathrm{pH}$ de la solución desciende, lo cual repercute en un menor grado de reacción de la ceniza (14) y, por tanto, en menores resistencias mecánicas.

\section{CONCLUSIONES}

Los estudios presentados en este trabajo sobre las variables que afectan a la elaboración de hormigones de ceniza volante activada alcalinamente (sin cemento OPC) son muy prometedores. Estos resultados muestran el potencial de estos materiales para que, en un futuro próximo, puedan ser utilizados en la industria de la construcción y, especialmente, en la industria de los prefabricados.

Las propiedades de los hormigones de ceniza volante activadas alcalinamente están influenciadas, al igual que las de los hormigones convencionales, por un conjunto de factores relacionados con la dosificación de la mezcla y con las condiciones de curado. No obstante, estos nuevos hormigones permiten desarrollar muy elevadas resistencias a cortas edades (1 día), resistencias que siguen progresando de forma más lenta con el paso del tiempo.

A nivel macroscópico las diferencias en la apariencia física entre un hormigón de cemento Portland y un hormigón alcalino de ceniza volante son prácticamente nulas. Las diferencias reales se encuentran a nivel microestructual y composicional.

\section{AGRADECIMIENTOS}

Los autores de este trabajo quieren dar las gracias a la Dirección General de Investigaciones Científicas, por la financiación del proyecto BIA2004-04835. A. FernándezJiménez también agradece al CSIC la financiación del contrato I3P ((REF. 13P-PC2004L) co-financiado por el Fondo Social Europeo. Finalmente, gracias a J. L. García y A. Gil por su colaboración en los ensayos mecánicos.
Finally, these problems of poor workability and consolidation are accompanied by a lesser degree of reaction when the waterglass content in the system rises. When this occurs at the expense of the $\mathrm{NaOH}$, the $\mathrm{OH}$ ion content in the medium declines. The resultant drop in $\mathrm{pH}$ lowers the degree of reaction of the ash (14) and, ultimately, mechanical strength.

\section{CONCLUSIONS}

The findings reported in this paper on the variables that affect the manufacture of (OPC-free) alkali-activated fly ash concrete are very promising. These results show the potential for use of such materials in the near future in construction and in particular in the pre-cast concrete industry.

The properties of alkali-activated fly ash concrete, like the characteristics of conventional concrete, are affected by a series of factors related to mix dosing and curing conditions. Contrary to conventional concrete, however, these new types of concrete can attain high strength in very short times (1 day) and subsequently develop further strength at a slower rate.

The macroscopic differences in the appearance of Portland cement and alkali fly ash concrete are practically nil: the actual differences are microstructural and compositional.

\section{ACKNOWLEDGEMENTS}

The authors wish to thank the Directorate General of Scientific Research under project BIA2004-04835; A. Fernández-Jiménez thank also to CSIC and co-financed by the European social fund for a I3P contract (REF. I3PPC2004L) The support provided by J. L. García and A. Gil in the mechanical testing is also much appreciated.

\section{BIBLIOGRAFÍA / BIBLIOGRAPHY}

(1) Talling, B. y Brandster, J.: "Present state and future of alkali-activated slag concretes", $3^{\text {rd }}$ International Conference of Fly Ash, Silica Fume, Slag and Natural Pozzolans in Concrete, Tondheim, SP 114-74 (1989), pp. 1519-1546.

(2) Glukhovsky, V. D., Rostovskaja, G. S. y Rumyna, G.V.: "High strength slag-alkaline cements", 7th International Congress on the Chemistry of Cement, París, 3, V-164-168 (1980).

(3) Puertas, F.: "Cementos de escorias activadas alcalinamente; situación actual y perspectivas de futuro", Mater. Construcc., vol 45, no 239 (1995), pp. 53-64. 
(4) Malek, R. I. A. y Roy, D. M.: "Structure and properties of alkaline activated cementitious materials", 97th annual meeting of the American Ceramic Society, Cincinati, OH, 1995.

(5) Fernández-Jiménez, A., Puertas, F. y Palomo J. G.: "Alkali-Activated Slag Mortars: Mechanical Strength Behaviour", Cem. Concr. Res., vol. 29 (1999), pp. 1313-1321.

(6) Puertas, F. y Fernández-Jiménez, A.: "Mineralogical and microstructural characterisation of alkali-activated fly ash/slag pastes", Cem. and Concr. Comp., no 25 (2003), pp. 287-292.

(7) Davidovits, J.: "Properties of geopolymer cements", First International Conference of Alkaline Cements and Concretes, Ukraine, Kiev, 1994, pp. 131-149.

(8) Granizo, M. L., Alonso, S., Blanco-Varela, M. T. y Palomo, A.: "Alkaline activation of metakaolin: effect of calcium hydroxide in the products of reaction", J. Am. Ceram. Soc., no 85 [1] (2002), pp. 225-231.

(9) Krivenko, P. V., "Alkaline cements", en P. V. Krivenko (ed.): Alkaline cements and concretes, 1. Vipol Stock Company, Kiev., 1994, pp. 11-129.

(10) Palomo, A., Grutzeck, M-W., Blanco, M. T.: "Alkali-activated fly ashes a cement for the future", Cem. Concr. Res., vol. 29 (1999), pp. $1323-1329$.

(11) Fernández-Jiménez A. y Palomo, A.: "Alkali-activated fly ashes: properties and characteristics", 11 ${ }^{\text {th }}$ International Congress on the Chemistry of Cement (Durban, South Africa), vol. 3 (2003), pp. 1332-1340.

(12) Palomo, A., Alonso, S., Fernández-Jiménez, A., Sobrados, I. y Sanz, J.: "Alkaline activation of fly ashes. A 29Si NMR study of the reaction products", J. Am. Ceramic. Soc., no 87 [6] (2004), pp. 1141-1145.

(13) Van Jaarsveld, J. G. S., Van Deventer, J. S. J. y Lukey, G. C.: "The effect of composition and temperature on the properties of fly ash and kaolinite-based geopolymers", Chemical Engineering Journal, vol. 89 (2002), pp. 63-73.

(14) Fernández-Jiménez, A. y Palomo, A.: "Microstructure of alkali activated fly ash mortars: effect of the activator", Cem. Concr. Res., no 35 (2005), pp. 1984-1992.

(15) Fernández-Jiménez, A. y Palomo, A.: "Characterisation of fly ashes. Potential reactivity as alkaline cements", FUEL, nº 82 (2003), pp. 2259-2265.

(16) Palacios, M. y Puertas, F.: "Estudio de la estabilidad de aditivos superplastificantes y reductores de la retracción en medios fuertemente alcalinos", Mater. Construcc., vol. 54, no 276 (2004), pp. 65-86.

(17) Neville, A. M.: Properties of Concrete, Logman Publishers, Essex, 1997.

(18) Sylla, M.H.: "Reactions in Cement Paste Due to Heat Curing" (in German), Beton, no 38 [11] (1988), pp. 449454; ver también: Wieker, W. y Herr, R.: "On Some Problems of the Chemistry of Portland Cement", Fur Chem., no 29 (1989), Zeitsch, pp. 321-327.

(19) Skalny, J., Johansen, V., Thaulow, N. y Palomo, A.: "DEF as a form of sulfate attack", Mater. Construcc. (1996), pp. 5-29.

(20) Taylor, H. F. W.: "Delayed Ettringite Formation", Advances in Cement and Concrete (M. W. Grutzek \& S.L. Sarkar, eds.), American Society of Civil Engineers, 1994; ver también: "Sulfate Reactions - Microstructural and Chemical Aspects", Cement Technology, Ceramic Transactions, 40 (1994), pp. 61-78.

(21) Scrivener, K. L. y Taylor, H. F. W.: "Delayed Ettringite Formation: a Microstructural and Microanalytic Study", Adv. Cem. Res., no 5 (1993), pp. 139-146.

(22) San-José, J. T. y Frías, M.: "High performance polymer concrete", Mater. Construcc., vol. 57, no 286 (2007), pp. 29-39.

(23) Fernández-Jiménez, A. y Palomo, A.: "Empleo de nuevos materiales en prefabricación: hormigones de ceniza volante activada" 1 er Congreso Nacional de Prefabricados, Madrid, España, 22-24 de mayo de 2002.

(24) Fernández-Jiménez, A. y Palomo, A.: "Activating fly ashes: Enlarging the concept of cementitious material", International Symposia "Celebrating Concrete: People and Practice", Dundee, 2003.

(25) Fernández-Jiménez, A. y Palomo, A.: "Hormigones alcalinos exentos de cemento Portland", Revista Ingeniería de Construcción, vol. 18, no 3 (2003), pp. 123-131.

(26) Hardjito, D., Wallah, S. E. y Rangan, B. V.: "Research into Engineering Properties of Geopolymer Concrete", International Conference 'Geopolymer2002 - tur potential into profit', Melbourne, Australia, 29 de octubre de 2002.

(27) Palomo, A., Fernández-Jiménez, A. y Criado, M.: "Geopolymers: one only chemical basis, some different microstructures", Mater. Construcc., vol. 54, no 275 (2004), pp. 77-91.

(28) Palomo, A., Fernández-Jiménez, A., López-Hombrados, C. y Lleyda, J. L.: "Precast elements made of alkali-activated fly ash concrete", $^{\text {th }}$ CANMET/ACI International Conference on fly ash, silica fume, slag and natural pozzolans in concrete. Las Vegas, USA (2004), 23-29 de mayo, Ed. V.M. Malhotra, ISBN: 0-87031-146-8.

(29) Fernández-Jiménez, A., Palomo, A., Sobrados, I. y Sanz, J.: "The role played by the reactive alumina content in the alkaline activation of fly ashes", Microporous and Mesoporous Materials, 91 (2006), pp. 111-119.

(30) Fernández-Jiménez, A., Palomo, A. y Criado, M.: "Alkali activated fly ash binders. A comparative study between sodium and potassium activators", Mater. Construcc., vol. 56 (2006), no 281, pp. 51-65. 